\title{
Possibilities of organizing agro-touristic routes in the Fergana Valley, Uzbekistan
}

\author{
Shokhsanam Yakubjonova ${ }^{1, *}$, Ziyoda Amanboeva ${ }^{1}$, and Gulnaz Saparova ${ }^{2}$ \\ ${ }^{1}$ Tashkent State Pedagogical University, Bunyodkor Road, 27, Tashkent, 100183, Uzbekistan \\ ${ }^{2}$ Tashkent State Agrarian University, University str., 2, Tashkent province, 100140, Uzbekistan
}

\begin{abstract}
The Fergana Valley, which is rich in nature and is known for its temperate climate, is characterized by the fact that it combines many aspects of the country's agritourism. As a result of our research, we have identified the Fergana Valley as a separate agro-tourist area. The region is rich in high mountains, medium mountains, low mountains (hills), central desert plains, irrigated (anthropogenic) plains, and a wide range of agrotouristic potential and opportunities. The creation and development of new tourist destinations is great importance to increase the economic potential of the country. This article describes the possibilities of agrotourism of the Fergana valley. The purpose of the work is an identification of agro-tours and organization of agro-tourist routes on the basis of the analysis of agro-tourism potential and opportunities of Fergana agro-tourist region.
\end{abstract}

\section{Introduction}

New prospects for tourism are opening up in our country, and large-scale projects are being implemented in various directions. In particular, in recent years, new types of tourism such as ecotourism, agrotourism, mountaineering, rafting, geotourism, educational tourism, medical tourism are gaining popularity [1-4]. Today, it is important to develop the types of tourism in the regions by studying their tourism potential $[1,3]$.

The Fergana Valley, which is rich in nature and is known for its temperate climate, is characterized by the fact that it combines many aspects of the country's agritourism. As a result of our research, we have identified the Fergana Valley as a separate agro-tourist area. The region is rich in high mountains, medium mountains, low mountains (hills), central desert plains, irrigated (anthropogenic) plains, and a wide range of agrotouristic potential and opportunities. Through the use of these potentials and opportunities in agritourism, new jobs and additional sources of income will be created [4-7].

The purpose of the work is an identification of agro-tours and organization of agrotourist routes on the basis of the analysis of agro-tourism potential and opportunities of Fergana agro-tourist region.

In the assessment of agro-tourism potential and opportunities of Fergana agro-tourist region, the analysis of agro-tourist potential of the components of the nature of the region -

\footnotetext{
* Corresponding author: shoxsanam1971@mail.uz
} 
relief, climate, water, soil and vegetation, fauna and agro-landscapes plays a key role. The Fergana region is located in the far east of Uzbekistan, in the tectonic basin Fergana Valley (part of the Fergana Valley belonging to Uzbekistan) between the Tianshan and Alay mountain ranges. The area is surrounded by mountains. The region is surrounded by Turkestan and Alay in the south, Fergana and Otoynak in the east, Chatkal in the north, Qurama and Karamazor mountain ranges in the northwest, and Mugultog in the west [8$11]$.

Only from the west the district is narrow $(8-9 \mathrm{~km})$ and is connected with the Dalvarzin and Mirzachul plains through the Fergana or Khojand gates. Administratively, it includes Namangan, Andijan and Fergana regions.

Fergana region is the main cotton-growing region in the country. In addition to cotton, wheat, corn, oats, rice, fruits - apples, quinces, cherries, peaches, pears, almonds, walnuts, figs, pomegranates, grapes, vegetables - tomatoes, potatoes, carrots, melons - melons, watermelons, cucumbers such as agricultural products are grown [2, 4]. Livestock such as cattle breeding, sheep breeding, goat breeding, poultry farming, silkworm breeding, and beekeeping are developed [2].

The diversity of natural geographical conditions and resources in the Fergana region, the diversity of agro-tourist opportunities and their peculiarities in different altitude zones under the influence of altitude zoning allow us to distinguish 6 sub-regions that differ from each other in the region: Western Alay, Central Plain, Govasay, Chatkal, Fergana and East Chatkal [7].

The western Alay agro-tourist subdistrict occupies the tributaries of the Sokh and Isfara rivers and the northern part of the northern slope of the Alay ridge, which belongs to this river basin, and is divided into plains and foothills. The south-western part of Besharik, Dangara, Uzbekistan, Furkat districts, Rishtan, Baghdad, Buvayda, Yangikurgan, Altiyarik districts are located in the territory of the small district.

The climate of the region is dry; the average annual rainfall is around $100 \mathrm{~mm}$. However, the region differs from other small regions in the agro-tourist region of Fergana by the mildness of winter and the lack of cold days [4-6].

In the region the ancient cities of Kokand and Rishtan are located. Many historical tourist facilities in Kokand (Norbutabiy Madrasah (1798), Daxmai Shahon Complex (1825), Khudoyorkhan Ordasy (2nd half of the 19th century)), Mosque (1st quarter of the 19th century) allow to combine agritourism with historical tourism. Pottery has been developed in Rishtan since ancient times, and the products of potters were in great demand in the Eastern markets. Art works made by Rishtan masters are now popular outside the country. As Rishtan is located on the right bank of the Sokh River and Kokand-is situated on the Fergana highway, it creates a good chance for tourists' visit and rest.

The region has well-developed agricultural sectors such as cotton growing, grain growing, vegetable growing, horticulture, cattle breeding, sheep breeding, poultry farming, silkworm breeding, beekeeping. In the fields you can see grain, cotton, vegetables and melons. And in the gardens apricots, pomegranates, figs, apples, dates, high-quality grapes are grown. Besharik and Altiariq have been familiar with their melons, while Buvayda for its fruits (e.g., white figs).

The people of the region have long been engaged in agriculture and cattle. As a result, agricultural traditions which are related to national customs and rituals were formed. It is possible to organize tourism in the region from the eve of Navruz to the autumn harvest. May and October are the best months for the tourist season. During this period, seasonal festivals are organized by the locals.

There are convenient access to the Fergana Valley and all other regions of the country by road. Also, the existing system of hotels and service outlets here allows to organize agritourism services. 
The territory of the Central Plain agro-tourist subdistrict is located in the central part of the Fergana region. It is bordered on the north by the Syrdarya, on the south by the foothills of the mountains and stretches in the Altiyarik, Soh and Shohimardon enclaves. This area is called the Karakalpak Desert. Its absolute height ranges from $350 \mathrm{~m}$ in the north along the Syrdarya to $500 \mathrm{~m}$ in the south, and up to $3000 \mathrm{~m}$ in the enclaves [5].

The climate of the region is characterized by aridity, richness of thermal resources, the presence of small lakes, swamps, sand massifs, and a relatively small variety of landscapes. The territory of the small region is occupied by geomods 29 and 33. The small agro-tourist region of the central plain is less important in terms of agrotourism [3]. In agriculture, cotton, grain and melons, fruits are grown, sheep breeding, goat breeding and cattle breeding are developed. In order to protect the sandy deserts, in 1991 the natural monument "Yazyavon deserts" (area 1842 ha) was established. The Yazyavan monument is an interesting tourist attraction for tourists. It is possible to organize seasonal short-term tourism in the region [3-5].

The Govasay agro-tourist subdistrict includes the south-eastern slope of the Syrdarya River with an absolute height of 350 m from the Qurama Mountain to the Kamchik Pass. The small district is a drier, colder winter area than the Chatkal small district. It includes Pop, Chust districts. The main branch of agriculture here is cotton growing, which accounts for 8-9 percent of the cotton grown in the country. In addition to cotton, grain growing, melon growing, viticulture and animal husbandry are developed. The region is rich in archeological monuments. Buonamozor on the northern outskirts of Chust, the land of ancient knife-makers and doppidozs, Munchoktepa monuments in Pop has great scientific and spiritual value. The rural areas of Gova, Olmos, Chorkesar, Chodak are rich in attractive tourist attractions. In the irrigated areas of the plains, livestock is mainly cattle, sheep and goats, yearlings in the foothills. There is a forest, mulberry, garden and perennial trees, and vineyards. Namangan district is famous for the diversity of apple varieties and their rich harvest. The region has the opportunity and conditions to organize the reception and recreation of tourists throughout the year. It is expedient to combine agro-tourism in the region with ecological, historical and archeological types of tourism.

The Chatkal agro-tourist subdistrict occupies the southern foothills of the Chatkal Mountains in Uzbekistan and is bordered by the Naryn River in the east and the Syrdarya River in the south. The small region differs from other regions by the high amount of precipitation, mild winters, and rich in thermal resources. Its territory includes Turakurgan, Kosonsoy, Namangan, Yangikurgan, Uychi, Chartak districts. The cultural landscapes of the oasis cover half of the region's territory.Many historical tourist sites in the small area have been preserved to this day. For example, in the city of Namangan (Khoja Amin mausoleum (17th century), Mulla Kyrgyz madrasah (1911-12), Ota Valikhan Tora mosque (20th century), the ruins of the ancient city of Aksikent in Turakurgan, Goyibnazar qazi madrasah (1892), Falosbonbuva (1860), Langarbibi mausoleums (18th century), Isakhantora (1806) mosques. Chartak, Uychi, Yangikurgan districts, which are part of the region, are distinguished by their tranquil nature and fertile fields. Their agro-tourism potential is explained by the richness of agro-tourist facilities (cotton, grain, potatoes, vegetables and melons are grown, cattle and sheep are raised on farms) and the convenience of natural conditions for recreation (e.g. Chartak, Shahand sanatoriums serve year-round vacationers).

In the Chatkal agro-tourist small district there is an opportunity to organize year-round agro-tourism.May-October is a special season for tourists. Combining agro-tourism with historical and recreational tourism gives high results.

The Fergana agro-tourist subdistrict includes alluvial-proluvial plains located on the south-western slope of the Fergana ridge and a part of the Karadarya valley. Its territory 
includes Asaka, Bulakbashi, Marhamat, Khojaabad, Kurgantepa, Kuva, Fergana, Toshloq, Kushtepa, Shahrihan, Jalal-Abad districts, the southern part of Boz district.

Due to the high amount of precipitation in the small area, the natural humidity is sufficient. The natural conditions of the region allow the development of almost all sectors of agriculture.Cultural landscapes in the area form large areas. In agriculture, cotton, cereals, vegetables and melons, fruits and grapes are grown, horticulture, cattle breeding, sheep breeding, poultry farming, silkworm breeding. According to the "Program of priority measures for the development of tourism in 2018-2019" in Fergana district on the basis of the agro-industrial company "Mindonobod" agro-tourism complex and excursions to the vineyards and wine production, there are favorable conditions for the organization of yearround tourism in the region. It has a well-developed diversified infrastructure. East Chatkal agro-tourist subdistrict includes the northernmost part of the northern slope of the Alay Mountains, where the basins of the Shohimardon, Isfaramsay, Aravonsay, Akbura, Kurshab rivers are located. These lands consist of hills, between the hills and beyond the hills, on the surface of the Altiariqsay, Shohimardonsay, Isfaramsay and Aravansay. Its territory includes Uchkurgan, Naryn, Andijan, Balikchi, Izbaskan, Altynkul and Pakhtaabad districts.

Owing to the relatively high altitude of the small region and its location in the northern exposition, there is a slight shortage of summer thermal resources, but a variety of landscapes. More than 50 percent of the district's territory is covered by cultural landscapes. The small district has a large experimental school of cotton growing. Cotton, cereals, potatoes and melons are grown. The establishment of orchards and mulberry groves on large areas, the development of such areas as animal husbandry, horse breeding, silkworm breeding, and poultry farming create favorable conditions for agritourism.

There are 11 hills and 5 architectural monuments in the region. These are the Andijan mosque (late 19th century), the shrines of Khovskonota, Koktonlikota, Kilich Ibrahim, Khoja Taksimota and others. The infrastructure in the district is well developed [4-8].

It is possible to organize long and short-term tourism throughout the year. Tourists are offered accommodation in hotels or private farms, participation in celebrations and ceremonies, dishes made from natural products in the national style.

In short, each small agro-tourist region has its own tourist resources. They also differ in the fact that the conditions for conducting tourist routes are at different levels. The tourist prestige of a particular country or region is directly determined by a number of indicators, such as the specific attractiveness, convenience, affordability, safety, level of service of tourist routes in them.

\section{Materials and methods}

Methods of organizing and conducting tourist routes are reflected in the work of such researchers as V.S. Volkov, K.E. Shapakina, S.R. Erdavletov, N. Tukhliev, T. Abdullaeva, R. Hayitbaev, and A. Sattarov [1, 2, 5-9].

The concept of tourist route has been defined differently by scientists. N. Tukhliev and T. Abdullaeva describes the tourist route as "pre-determined routes of tourist movement (excursion, travel) defined in a certain order by geographical points". In the research of S.R. Erdavletov, the tourist route is defined as "the route of a group of tourists through certain destinations on the basis of a predetermined schedule". Tourism, as we all know, can be carried out in groups or individually.

Based on the descriptions of tourist routes, agro-tourist routes can be described as follows: Agrotouristic route is a way of movement of a tourist or a group of tourists on predefined objects in order to get acquainted with interesting tourist processes of cultivation, processing and sale of agricultural products of a certain place (Table 1). 
Table 1. Tourist resources and opportunities of Fergana agro-tourist region.

\begin{tabular}{|c|c|c|c|}
\hline : & Agrotouristic facilities & Other tourist attractions & Infrastructure \\
\hline 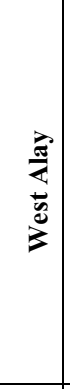 & $\begin{array}{l}\text { Crops: cotton, cereals, } \\
\text { corn, melons, vegetables, } \\
\text { forests, orchards. } \\
\text { Livestock complexes: } \\
\text { cattle breeding, sheep } \\
\text { breeding, goat breeding, } \\
\text { poultry farming, silkworm } \\
\text { breeding, beekeeping. }\end{array}$ & $\begin{array}{l}\text { Historical and architectural monuments: } \\
\text { Orbutabiy madrasah (1798), Daxmai Shahon } \\
\text { complex (1825), Khudoyorkhan (2nd half of } \\
\text { 19th century), Mosque (1st quarter of 19th } \\
\text { century). } \\
\text { Archaeological monuments: Zuraymomo hill } \\
\text { (6th century BC), Kitkonkala (1st and 4th } \\
\text { centuries). } \\
\text { Natural monuments: Selengur, Kapchigay } \\
\text { cave. } \\
\text { Folk national crafts: pottery. }\end{array}$ & $\begin{array}{l}\text { Railways: Tashkent- } \\
\text { Kokand, Tashkent- } \\
\text { Namangan, Tashkent- } \\
\text { Andijan, Margilan- } \\
\text { Kokand, Andijan- } \\
\text { Moscow, Bishkek- } \\
\text { Jalal-Abad. } \\
\text { Highways: Tashkent- } \\
\text { Osh-Kashgar, Kokand- } \\
\text { Khojand, Fergana-Osh, } \\
\text { Kokand-Namangan, } \\
\text { Kokand-Jamashoy }\end{array}$ \\
\hline 焉 & $\begin{array}{l}\text { Crops: cotton, melons, } \\
\text { pomegranates } \\
\text { Livestock complexes: } \\
\text { cattle breeding, goat } \\
\text { breeding, sheep breeding. }\end{array}$ & Natural monuments: Yazyovan deserts. & $\begin{array}{l}\text { Highways: Fergana- } \\
\text { Namangan, Kokand- } \\
\text { Andijan, Tashkent- } \\
\text { Fergana, Margilan- } \\
\text { Kokand. } \\
\end{array}$ \\
\hline 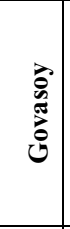 & $\begin{array}{l}\text { Crops: cotton, vegetable } \\
\text { crops, orchards, vineyards, } \\
\text { forests } \\
\text { Livestock complexes: } \\
\text { cattle breeding, sheep } \\
\text { breeding, goat breeding, } \\
\text { silkworm breeding. }\end{array}$ & $\begin{array}{l}\text { Archaeological monuments: Buonamozor, } \\
\text { Munchoqtepa. } \\
\text { Folk national handicrafts: knife-making, hat } \\
\text { making. }\end{array}$ & $\begin{array}{l}\text { Railways: Tashkent - } \\
\text { Andijan. } \\
\text { Highways: Fergana ring } \\
\text { road. }\end{array}$ \\
\hline 焉 & $\begin{array}{l}\text { Crops: cotton, vegetable } \\
\text { crops, orchards, vineyards. } \\
\text { Livestock complexes: } \\
\text { cattle breeding, sheep } \\
\text { breeding, goat breeding, } \\
\text { silkworm breeding. }\end{array}$ & $\begin{array}{c}\text { Historical and architectural monuments: } \\
\text { Khoja Amin mausoleum (17th century), } \\
\text { Mulla Kyrgyz madrasah (1911-12), Ota } \\
\text { Valikhan tora mosque (20th century), } \\
\text { Goyibnazar qazi madrasah (1892), Falos- } \\
\text { bonbuva (1860), Langarbibi mausoleums ( } \\
\text { 18th century), Isakhantora mosque (1806). } \\
\text { Archaeological monuments: Akhsikent, } \\
\text { Akhsi ruins. } \\
\text { Recreation facilities: Shakhand, Pakhtalikul, } \\
\text { Chartak sanatoriums } \\
\end{array}$ & $\begin{array}{c}\text { Railways: Fergana } \\
\text { bypass railway, } \\
\text { Tashkent-Namangan- } \\
\text { Andijan, Tashkent- } \\
\text { Andijan, } \\
\text { Highways: Namangan- } \\
\text { Chartak-Nanay. } \\
\text { Airlines: Tashkent - } \\
\text { Namangan. }\end{array}$ \\
\hline 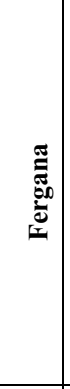 & $\begin{array}{c}\text { Crops: cotton, cereals, } \\
\text { corn, melons, } \\
\text { pomegranates, figs, } \\
\text { vineyards, orchards. } \\
\text { Livestock complexes: } \\
\text { cattle breeding, sheep } \\
\text { breeding, horse breeding, } \\
\text { goat breeding, silkworm } \\
\text { breeding, poultry farming, } \\
\text { beekeeping, fishing. }\end{array}$ & $\begin{array}{c}\text { Historical and architectural monuments: } \\
\text { Lonkontepa shrine from Babur's shrines, } \\
\text { Ponsod mosque (1825, UNESCO list). } \\
\text { Archaeological sites: Kamoltepa (1-4 } \\
\text { centuries), Dalvarzintepa, Qoratepa, } \\
\text { Eshantoga, Kilichmozor hills. } \\
\text { Recreation facilities: Chimgan, Zilol, } \\
\text { Nurafshan sanatoriums, recreation area } \\
\text { "Asaka pocket". } \\
\text { Folk national handicrafts: Shahrikhan knife- } \\
\text { making, Margilan doppichilik and silk- } \\
\text { making }\end{array}$ & $\begin{array}{l}\text { Railways: Fergana } \\
\text { Valley Ring Road. } \\
\text { Highways: Fergana- } \\
\text { Shohimardon, Fergana- } \\
\text { Andijan, Andijan- } \\
\text { Margilan, Vodil- } \\
\text { Altiariq, } \\
\text { Airlines: Tashkent - } \\
\text { Fergana. }\end{array}$ \\
\hline 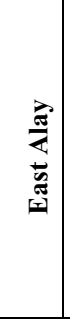 & $\begin{array}{l}\text { Crops: cotton, cereals, } \\
\text { corn, melons, } \\
\text { pomegranates, figs, } \\
\text { vineyards, orchards. } \\
\text { Livestock complexes: } \\
\text { cattle breeding, sheep } \\
\text { breeding, goat breeding, } \\
\text { horse breeding, silkworm } \\
\text { breeding, poultry farming, } \\
\text { beekeeping, fishing. }\end{array}$ & $\begin{array}{l}\text { Historical and architectural monuments: } \\
\text { Andijan mosque (end of the 19th century). } \\
\text { Hovskonota, Koktonlikota, } \\
\text { Sword Abraham, } \\
\text { Shrines of Khoja Taksimota }\end{array}$ & $\begin{array}{c}\text { Railways: } \\
\text { Andijan - Uchkurgan, } \\
\text { Andijon - Tentaksoy, } \\
\text { Highways: } \\
\text { Andijon - Jalolobod, } \\
\text { Osh - Bishkek. } \\
\text { Airlines: } \\
\text { Tashkent - Andijan. }\end{array}$ \\
\hline
\end{tabular}


The development of tourist routes is based on several general principles (guiding rule). They can also be improved and applied to agro-tourist routes. V.S. Volkov and K.E. Shapakina divide tourist routes into three types according to the possibility of arrival and departure of tourists $[1,2,8,9]$ :

1. One-way oriented (straight line).

2. Directed from one place to different sides (radial).

3. Coming back to the same place from where it started (rotation).

Agrotouristic routes can be divided into the following types according to the classification criteria (characteristics of tourist facilities within the route):

1. Pure agrotouristic routes. These are routes designed to acquaint tourists with the rural lifestyle and agro-tourist facilities.

2. Routes aimed at combining agro-tourism and ecotourism. This type of route is designed to accommodate and provide services to tourists in rural areas, to demonstrate the attractiveness of the environment, to protect beautiful natural landscapes, to use natural resources wisely, to preserve ancient agricultural practices, to apply environmental measures based on traditions.

\section{Results and discussion}

Routes aimed at combining agro-tourism with other types of tourism. In this tour, tourists are introduced to the natural, ecological, historical, ethnographic, religious, spiritual and educational objects of the rural area.

In our study, agro-tourist areas of the Fergana region were identified that meet the agrotourist opportunities, and data were collected in order to attract tourists to the routes. On this basis, a map "Tourism opportunities and routes of the Fergana agro-tourist region" at a scale of 1: 400,000 was created (see Fig. 1).

More than a dozen routes have been identified and classified according to their characteristics, taking into account the full use of the tourist potential of the Fergana Valley (in the part of Uzbekistan):

I. Pure agro-tourist routes:

1. Kokand - Beshariq.

2. Kokand - Buvayda.

3. Andijon - Asaka - Marhamat.

4. Andijan - Poytug - Haqqulobod.

5. Andijan - Khojaabad - Kurgantepa.

6. Andijan - Shahrihan.

II. Routes aimed at combining agrotourism and ecotourism:

1. Fergana - Vodil - Shohimardon.

2. Namangan - Kosonsoy - Yangikurgan.

3. Namangan - Chartak - Uchkurgan.

III. Complex routes aimed at combining agro-tourism with other types of tourism:

1. Fergana - Rishtan.

2. Fergana - Margilan - Kuva.

3. Namangan - Chust - Pop.

As an example, a route for each type was described. The description contains information about the duration of the route, duration, direction, nature of the area, agrotourism and other types of facilities.

Andijan-Asaka-Marhamat route. Duration: September-October. Destination: Andijan city - Asaka city - Marhamat district - Andijan city. The duration of the route is 1 day. 
Tourists are offered a one-day itinerary around Andijan region. Tourists are offered a one-day itinerary around Andijan region. The route can attract many tourists due to the large number of car parks, ease of access to excursion facilities, attractions. The route passes through the areas of specialized farms, during the route tourists can get acquainted with the activities of cotton fields, melons, livestock farms. The route starts from Andijan. Andijan is located in the east of the Fergana Valley, on the banks of the Andijan River, at an altitude of $450 \mathrm{~m}$ above sea level. Excursions can be organized to acquaint tourists with the sights of the city. During the trip, tourists can get acquainted with the activities of agrotourist facilities around the villages of Ittifoq, Kandy, Dong - arable lands, orchards, vineyards and farms. The route leads through the Asaka district center to the Asaka Adir Reservoir. The reservoir and its surroundings are an important recreational facility for tourists. The Shahrikhansay and Katta Fergana canals, which flow through the area, are the main irrigation facilities supplying water to irrigated crops. In the area there is the "Asaka pocket", one of the most charming and beautiful corners of nature. In the afternoon, the route will continue through the villages of Khojaariq, Bobokhuroson, Hakka. Rural areas have been developed since ancient times, are relatively well supplied with water, and arable lands are irrigated from Greater Fergana and Aravonsay. The visit of tourists coincides with the time of ripening. Fruits, grapes, melons and watermelons are grown in the gardens. Many farms in the region grow cotton, wheat, vegetables, melons and gourds, and raise cattle, sheep, poultry, and yearlings. Due to the harvest season at this time, the farms hold harvest festivals. It is possible to organize meaningful recreation on the farms for tourists. The route ends in the town of Marhamat.Fergana - Vodil - Shohimardon route (along Shohimardonsoy). Duration: May - June. Route: Fergana city - Vodil village Shohimardon village - Fergana city. The duration of the route is 1 day.

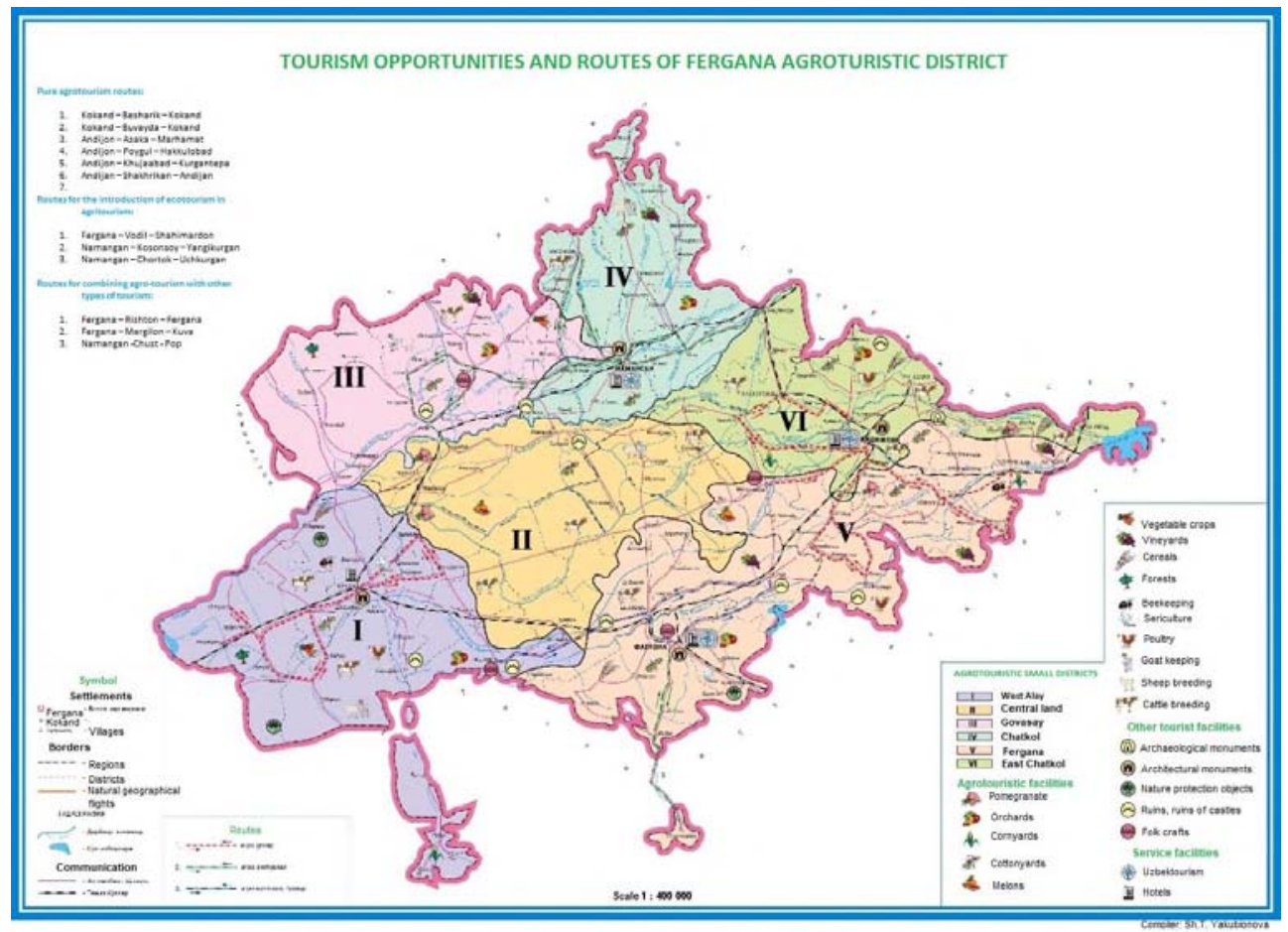

Fig. 1. Tourism opportunities and routes of the Fergana agro-tourist region. 
The route is distinguished by the fact that it covers both ecotourism and ecotourism. During the route, tourists will be given excursions to places of interest and recreation. The route begins with a tour of the sights of Fergana. The city is located in the southern part of the Fergana Valley, at the foot of the Alay Mountains, at an altitude of $580 \mathrm{~m}$ above sea level. Along the way, tourists will visit cotton fields, wheat fields and orchards located in the rural areas of Mindonabad, Shohimardonabad and Yoshlarabad. The excursion coincides with the beginning of the cotton harvest in the fields, where the cotton stretches to a flat height.Tourists stop and rest in the village of Vodil in the afternoon. Vodil is located on the shores of Shohimardonsoy. His unique nature captivates man. Cotton, wheat, fruits and vegetables, melons are grown in the valley, cattle, sheep and goats are grazed on the pastures. Tourists can taste fresh fruits and vegetables and eat traditional dishes.

In the afternoon, the route will continue along Shohimardonsoy. Shohimardonsoy is formed by the confluence of the Aksu and Koksuv rivers (near the village of Shohimardon), which begin on the northern slopes of the Alay and Turkestan ridges. From the village of Vodil to the city of Fergana is called Margilansay, and below it Shohimardonsay. There are Shohimardon, Aqqiya, Qumbulak, Langar and other villages in the river valley. The villagers are engaged in agriculture and animal husbandry. There are amenities along the river for tourists to get acquainted with the unique way of life of the villagers, national traditions (in the summer, the "Lake Qubbon" ceremonies are held). The route ends at Shohimardon.

Namangan - Chust - Pop route.Duration: May-June and August-September. Route: Namangan - Turakurgan - Chust - Pop - Namangan. The duration of the route is 1 day.

The route is of a complex nature and introduces tourists to historical, ecological and religious sites, as well as agro-tourist facilities.

The route starts from the city of flowers Namangan. The city is located at the intersection of the Northern Fergana Canal and Namangansay, at an absolute height of 450 m. Tourists will get acquainted with the modern appearance of the city, historical and architectural monuments - the mausoleum of Khoja Amin (17th century), Mulla Kyrgyz madrasah (early 20th century), Ota Valikhan Tora Mosque of the 20th century). Each mosque is built on the basis of its own architectural art and is decorated with beautiful patterns and inscriptions. The city also holds a regular "Flower Festival" in May each year. It will feature more than a thousand flower varieties. Florists from different regions of the country will visit the festival and demonstrate their varieties of flowers and experience in the field of floriculture. Leaving the city, the route continues outside the city through gardens and vineyards, Irvadon, Girvan villages. In the fields, cotton, wheat, vegetables, melons are at the same stage of development. Tourists visiting these places in the summer will enjoy early ripening varieties of melons (ditch, blueberry). In Turakurgan (Sohibkor farm), Chust (Govasoy farm) viticulture is local, its varieties are grown on private farms, and such varieties are grown on farms in the plains, hills and foothills.

If walked along the highway, you will come to the city of Turakurgan, located $12 \mathrm{~km}$ from the regional center. Kosonsoy flows past the city. Historical and architectural monuments of the city include Goyibnazar madrasah, Falosbonbuva, Langarbibi mausoleums. There is an archeological monument Akhsikent, which occupies 25 hectares, which went down in history as "Fergana Afrosiyobi". The Aksikent Shahristan is surrounded on three sides by high tower walls, and on the south side it crosses the Syrdarya, with relatively low walls.

The route leaves Turakurgan and enters Chust. The city is located on the northern edge of the Fergana Valley, $36 \mathrm{~km}$ west of Namangan, at an altitude of 1,000-1,200 $\mathrm{m}$ on the banks of the Chust River in the foothills. Chust is one of the ancient cities of the valley. Located on its northern edge, the Lower Bronze Age monument of the II millennium BC Buonamazor settlement was formed in the oasis of irrigated agriculture and entered science 
under the name of Chust culture. The city of Chust plays an important role in the development of the Great Silk Road international trade. Through this way, the fame of Chust blacksmiths, weavers, potters, jewelers, Chust knives and doppies became widespread. Also, the Mavlono Lutfullo complex and the park around it are a comfortable place for tourists. To the west of Chust are the villages of Tashkurgan and Mashhad. It is natural that ancient vineyards, orchards and arable lands have been formed here, which attract the attention of tourists. Tourists can take part in one of the festivities celebrated at this time. The hyacinth festival is held in the first week of May around the cave, spring and adjacent hyacinth grove on the banks of the Govasay. Celebrated for thousands of years, the national holiday "Sumbul siyoh" - the holiday of hyacinth - has become the value of the Chusts. Mass folk games, kurash, askiya, poetry, melodies will be performed at the festival.During the route, tourists will also get acquainted with the agro-tourist facilities in the villages of Gulbog, Sang, Toda, located along the Syrdarya River around the city of Pop. The route ends in the evening.

\section{Conclusions}

As a result of the study, the existing agro-tourist facilities in the Fergana Valley were identified and agro-tours were identified on their basis. Twelve routes have been developed across the region and a map of tourism opportunities and routes of the Fergana agro-tourist region has been created.A description of three routes from agrotourism routes was also given. The indicated agro-tourist routes are the results of preliminary research, which can be further supplemented, enriched and additional routes can be organized in other directions.

\section{References}

1. S. R. Erdavletov, Geography of tourism: history, theory, method, practice, 36 (2000)

2. A. N. Nigmatov, SH. T. Yakubjonova, Science and technology development and geography, 13-17 (2007)

3. V. Nilipovskiy, A. Inamov, International Multidisciplinary Scientific GeoConference Surveying Geology and Mining Ecology Management, SGEM, 2020-August(2.2), 343-350 (2020)

4. A. Inamov, I. Ruziev, S. Nurjanov, IOP Conf. Ser.: Mater. Sci. Eng., 1030(1), 012112 (2021)

5. N. Tuxliev, T. Abdullaeva, National Encyclopedia of Uzbekistan, 423 (2006)

6. SH. T. Yakubjonova, Agricultural development and ecology: Proceedings of the Republican scientific-practical conference, 85-90 (2009)

7. SH. T. Yakubjonova, Natural geographical aspects of agritourism: Dissertation work on Geography, 125 (2018)

8. R. Hayitboev, A. Sattarov, Technology of development of tourist routes, 87 (2009)

9. SH. Yakubjanova, Z. Amanbayeva, Polish journal of science, 30, 61 (2020)

10. S. Abdurakhmonov, I. Abdurahmanov, D. Murodova, A. Pardaboyev, N. Mirjalolov, A. Djuraev, InterCarto. InterGIS, 26, 319-328 (2020)

11. K. Karimova, S. Khikmatullaev, U. Kholiyorov, N. Mirjalalov, U. Islomov, F. Juraeva, IOP Conf. Ser.: Mater. Sci. Eng., 896(1), 012118 (2020) 